\title{
Rozhodnutí Rady EU - žaloba České republiky ve světle rozhodnutí o relokaci a žaloby s ním související
}

\author{
Michael Pauly \\ Západočeská univerzita v Plzni, Fakulta právnická
}

Anotace: $V$ prvé řadě se $v$ přispěvku podává obecný rozbor rozhodnutí Rady EU č. 2015/1523 a č. 2015/1601, která byla přijata za účelem řešení migrační krize, stanovení relokačních kvót a řešení problematiky osob žádajících o azyl a jejichž motivem bylo zjevně poskytnutí mezinárodní ochrany těmto osobám z Řecké republiky a Italské republiky.

Dále příspěvek předkládá vymezení základních pojmů souvisejících s uvedenou řešenou problematikou, zejména pojmů azyl, azylant, relokace, relokační nařizení, dublinský systém apod.

$\mathrm{Z}$ hlediska podstaty rozebírané materie jsou v přispěvku především nastíněny základní kontury Lisabonské smlouvy, přičinná souvislost mezi prijetím Lisabonské smlouvy a právní závazností relokačních kvót pro členské státy EU, zásadní změny právní úpravy, které Lisabonská smlouva přináši, zejména v podobě hlavy $V$ Smlouvy o fungování Evropské unie (dále též „SFEU“), kde se nově zavádí sdílené kompetence 
v oblasti azylu, migrace, ochrany vnějších hranic a policejní a justični spolupráce $v$ trestních i civilních věcech. V návaznosti na uvedený výklad je pak v přispěvku rozebrána jednak žaloba směřující proti České republice, kterou dne 22. prosince 2017 podala k Soudnímu dvoru Evropská komise, a to $z$ důvodu údajného porušení povinností prijatých Českou republikou v oblasti relokací, a jednak proces této žalobě předcházející. Kromě toho je též rozebrána žaloba, kterou se Mad’arská republika, Slovenská republika a Polská republika (v postavení vedlejšího účastníka) domáhaly toho, aby Soudní dvůr rozhodnutí Rady EU přijaté dne 22. záři 2015 pod č. 2015/1601, stanovující povinné migrační kvóty pro členské státy EU, zrušil.

Klíčová slova: migrace, krize, relokace, kvóta, žaloba

Abstract: First of all, the thesis provides a general analysis of EU Council Decisions no. 2015/1523 and no. 2015/1601, which were accepted with the goals of solving the migration crisis, establoshing relocation quotas and tackling asylum seekers, who were apparently motivated by the provision of international protection of such persons from the Hellenic Republic and the Italian Republic.

Furthermore, the paper defines the basic concepts related to the issue, especially asylum, asylum seeker, relocation, relocation order, Dublin system and the like.

From the point of view of the material discussed, the paper outlines the basic contours of the Lisbon Treaty, the causal link between the adoption of the Lisbon Treaty and the legal binding effect of relocation quotas for EU Member States. Treaty on the Functioning of the European Union (TFEU), which newly introduces shared competences in the areas of asylum, migration, external border control and police and 
judicial cooperation in criminal and civil mattersis also part of the analysis.

Following the above interpretation, the paper examines the action against the Czech Republic brought by the European Commission on 22 December 2017 for alleged breach of the Czech Republic's relocation obligations and the proceedings. In addition, the action brought by the Republic of Hungary, the Slovak Republic and the Republic of Poland (intervening) is requesting a ruling from the Court of Justice of the EU to set the decision of the EU Council of 22 September 2015 under No. 2015/1601, which is laying down mandatory migration quotas for member states aside.

Keywords: migration, crisis, relocation, quota, lawsuit

\section{Úvod}

Relokační program, in concreto relokační nařízení Evropského parlamentu a Rady EU, reflektuje kritickou imigrační situaci na území dnešní Evropy. ${ }^{1}$ Státy Evropské unie tak byly $v$ souladu s tímto programem zavázány ke splnění relokačních kvót za účelem řešení migrační krize, která postihla zejména země EU, přičemž Česká republika měla na základě dvou relokačních rozhodnutí Rady EU prijatých v roce 2015 přijmout celkem 2691 migrantů z Řecké republiky a Italské republiky, kteři zjevně potřebovali mezinárodní ochranu. ${ }^{2}$

\footnotetext{
${ }^{1}$ Souhrnné informace o postupu MV v problematice relokací [online]. [cit. 2019-08-02]. Dostupné z: https://www.mvcr.cz/migrace/clanek/souhrnne-informace-o-postupu-mv -v-problematice-relokaci.aspx

${ }^{2}$ Souhrnné informace o postupu MV v problematice relokací [online]. [cit. 2019-08-02]. Dostupné z: https://www.mvcr.cz/migrace/clanek/souhrnne-informace-o-postupu-mv -v-problematice-relokaci.aspx
} 
Uvedený počet migrantů vznikl součtem tzv. dobrovolné a povinné kvóty, přičemž dobrovolnou kvótou, tj. kvótou určenou rozhodnutím Rady EU 2015/1523 ze dne 14. záŕi 2015, se Česká republika v souladu s rozhodnutím vlády České republiky č. 556/2015 ze dne 8 . července 2015 rozhodla dobrovolně přijmout 1100 osob z Řecké republiky a Italské republiky, čímž dala jednoznačně najevo, že je připravena vyzkoušet možnosti realizace a potenciální funkčnost relokací v dobrovolném režimu. ${ }^{3}$

V návaznosti na dobrovolnou kvótu vydala Rada EU dne 22. zárí 2015 rozhodnutí přijaté kvalifikovanou většinou členských států v Radě EU, a to s č. 2015/1601, jímž dobrovolnou kvótu dále rozšiřila o kvótu povinnou, čímž došlo k uložení povinnosti České republice přijmout dalších 1591 osob. ${ }^{4}$ Prijetí tohoto druhého relokačního rozhodnutí (2015/1601), které stanovilo povinné kvóty bez analýzy důsledků a implementace prvního rozhodnutí (2015/1523), bylo dle názoru České republiky, s nímž se Ize zřejmě ztotožnit, přinejmenším ukvapené, na což Česká republika opakovaně upozorňovala na jednáních Rady pro spravedlnost a vnitřní věci. ${ }^{5}$

\footnotetext{
${ }^{3}$ Souhrnné informace o postupu MV v problematice relokací [online]. [cit. 2019-08-02]. Dostupné z: https://www.mvcr.cz/migrace/clanek/souhrnne-informace-o-postupu-mv -v-problematice-relokaci.aspx

${ }^{4}$ Souhrnné informace o postupu MV v problematice relokací [online]. [cit. 2019-08-02]. Dostupné z: https://www.mvcr.cz/migrace/clanek/souhrnne-informace-o-postupu-mv -v-problematice-relokaci.aspx

${ }^{5}$ Souhrnné informace o postupu MV v problematice relokací [online]. [cit. 2019-08-02]. Dostupné z: https://www.mvcr.cz/migrace/clanek/souhrnne-informace-o-postupu-mv -v-problematice-relokaci.aspx
} 


\section{Přehled základních pojmů}

Ke správnému pochopení dané problematiky je potřebné vymezení základních pojmů, které jsou s touto problematikou těsně spojeny.

\subsection{Imigrace}

Imigrací se rozumí změna místa pobytu osoby z území jednoho státu na území státu jiného, který je od domovského státu této osoby zpravidla odlišný a z jehož pohledu se daná změna posuzuje. Jde do jisté míry, totiž z pohledu zmíněného domovského státu osoby, o opak ke slovu emigrace, jež pochází z latinského ex-migrare, což v překladu znamená vystěhování se, opuštění či útěk. Imigrace je přitom procesem, při němž se na území určitého státu usídlují cizinci. ${ }^{6}$

\subsection{Cizinec}

Z pohledu právního řádu České republiky je v souladu s ustanovením § 1 odst. 2 zákona č. 326/1999 Sb., o pobytu cizinců na území České republiky a o změně některých zákonů, ve znění pozdějších předpisů za cizince považována kterákoliv fyzická osoba, která není státním občanem České republiky, a to včetně občana Evropské unie. ${ }^{7}$

\footnotetext{
${ }^{6}$ Slovníček pojmů - imigrace [online]. [cit. 2019-07-29]. Dostupné z: https://www.mvcr. $\mathrm{cz} / \mathrm{migrace} / \mathrm{clanek} /$ slovnicek-pojmu.aspx

${ }^{7} \S 1$ odst. 2 zákona č. 326/1999 Sb., zákona o pobytu cizinců na územi České republiky a o změně některých zákonů.
} 


\subsection{Azyl}

Azylem se pro účely tohoto přispěvku rozumí ochranný status, který stát poskytuje státním příslušníkům jiných států, popřípadě osobám, které státní příslušnost nemají, v souvislosti s rizikem jejich pronásledování z důvodů přesně vyjmenovaných $v$ mezinárodních i národních právních dokumentech. V České republice obsahuje právní úpravu vymezující důvody udělení azylu zákon č. 325/1999 Sb., o azylu, ve znění pozdějších předpisů (dále též „zákon o azylu“). ${ }^{8}$

\subsection{Azylant}

Dle $\S 2$ odst. 2 zákona o azylu se za azylanta považuje cizinec, kterému byl dle tohoto zákona udělen azyl, a to po dobu platnosti rozhodnutí o udělení azylu. ${ }^{9}$

\section{5 Žadatel o azyl}

Článek 2 písm. c) nařízení Evropského parlamentu a Rady 604/2013 stanoví, že pro účely tohoto nařizení se žadatelem o azyl rozumí státní příslušník třetí země nebo osoba bez státní příslušnosti, kteří podali žádost o mezinárodní ochranu, o níž dosud nebylo pravomocně rozhodnuto. ${ }^{10}$

\footnotetext{
${ }^{8}$ Slovníček pojmů - azyl [online]. [cit. 2019-07-29]. Dostupné z: https://www.mvcr.cz/ migrace/clanek/slovnicek-pojmu.aspx

${ }^{9} \S 2$ odst. 2 zákona č. 325/1999 Sb., o azylu.

${ }^{10}$ Slovníček pojmů - žadatel o azyl [online]. [cit. 2019-07-29]. Dostupné z: https://www. $\mathrm{mvcr.cz/migrace/clanek/slovnicek-pojmu.aspx}$
} 
Rozhodnutí Rady EU - žaloba České republiky ve světle rozhodnutí o relokaci a žaloby s ním související / Michael Pauly

\subsection{Relokace}

Relokace neboli přemístění je převod žadatelů o azyl, kteří jednoznačně potřebuji mezinárodní ochranu, z jednoho členského státu Evropské unie či státu přidruženého k EU do jiného členského státu Evropské unie či státu přidruženého $\mathrm{k}$ EU.11

\subsection{Relokační nařízení}

Relokačním nařízením je nařizení Evropského parlamentu a Rady (EU) č. 604/2013 ze dne 26. června 2013, jinak též označované jako Dublin III nebo jako dublinský systém.

\subsection{Dublinský systém}

Dublinský systém je označení používané pro mechanismus, na základě kterého dochází $k$ určení státu příslušného k posouzení žádostí o mezinárodní ochranu, které podávají příslušníci třetích států na území členských států Evropské unie nebo států přidružených $\mathrm{k}$ EU..$^{12}$

\footnotetext{
${ }^{11}$ Questions and Answers on Relocation [online]. [cit. 2019-08-02]. Dostupné z: https:// www.easo.europa.eu/operational-support/hotspot-relocation/relocation/questions -and-answers-relocation

${ }^{12}$ Slovníček pojmů - dublinský systém [online]. [cit. 2019-07-29]. Dostupné z: https:// www.mvcr.cz/migrace/clanek/slovnicek-pojmu.aspx
} 


\section{2 Čeho vyplývá relokační povinnost}

Pro získání odpovědi na otázku právního základu relokační povinnosti je nezbytné nastínit základní kontury Lisabonské smlouvy ${ }^{13}$ a změny, které Lisabonská smlouva přinesla. Přijetím Lisabonské smlouvy došlo ke zrušení původní tzv. třípilířové struktury Evropské unie, následkem čehož vznikla soustava nová, jednopilírová, která byla důsledkem fúze naznačených tři piliřů, in concreto dosavadního I. pilíre EU, tj. komunitárního práva (s výjimkou Euratomu), dosavadního II. pilíre EU, tj. společných zahraničních a bezpečnostních politik, a dosavadního III. pilíre EU, tj. policejní a justiční spolupráce $v$ trestních věcech. ${ }^{14}$

Nová hlava V SFEU, kterou nově Lisabonská smlouva do SFEU zavádí pod názvem „prostor svobody bezpečnosti a práva“, obsahuje sdílené kompetence z oblasti azylu, migrace, ochrany vnějších hranic a policejní a justiční spolupráce v trestních i civilních věcech. ${ }^{15}$

Na základě nové právní úpravy, kterou Lisabonská smlouva přináší, dochází též k posílení pravomocí Soudního dvora ve věcech migrační a azylové politiky, nad kterou má tento soud nově plnou jurisdikci.

\footnotetext{
${ }^{13}$ Lisabonská smlouva - pozměňujíci Smlouvu o Evropské unii a Smlouvu o založení Evropského společenství, ze dne 13. prosince 2007. Úř. věst. C 306, 17. prosince 2007, s. 1-271.

${ }^{14}$ KRÁL, R. Acta Universitatis Carolinae. luridica. 2010, 3, str. 21-31 [online]. [cit. 201907-26]. Dostupné z: https://cupress.cuni.cz/ink2_stat/dload.jsp?prezMat=87969

${ }^{15}$ ŠKAPOVÁ, L. Relokace jako nástroj řešení migrační krize EU. Praha, 2019. Diplomová práce. Univerzita Karlova, Fakulta právnická. Str. 8. Dostupné z: https://dspace.cuni. $\mathrm{cz} / \mathrm{bitstream} / \mathrm{handle} / 20.500 .11956 / 108349 / 120334286$. pdf?sequence=1\&isAllowed $=y$
} 
Rozhodnutí Rady EU - žaloba České republiky ve světle rozhodnutí o relokaci a žaloby s ním související / Michael Pauly

V důsledku konstituování Listiny základních práv EU jakožto práva primárního jsou nyní práva, jakými jsou např. právo na azyl, ochrana v případě vystěhování, vyhoštění či vydání, výslovně garantována primárním právem EU. ${ }^{16}$

Lisabonská smlouva rovněž nastolila právní jistotu v oblasti jednotlivých pravomocí EU a pravomocí sdílených se členskými státy ${ }^{17}$. Tak tomu je např. v prípadě článku 4 odst. 2 SFEU, ve kterém je výslovně potvrzeno dosavadní pojetí, podle něhož pravomoci EU v oblasti prostoru svobody, bezpečnosti a práva patři mezi pravomoci sdílené s členskými státy a které mohlo před prijetím Lisabonské smlouvy vzbuzovat pochybnosti.

Přijetím Lisabonské smlouvy došlo k zásadním změnám co do rozsahu unijních pravomocí v oblasti azylu a migrace. Pravomoci EU v oblasti azylu, migrace a hraničních kontrol byly Lisabonskou smlouvou značně rozšiřeny. Článek 78 SFEU nově zakotvuje společné záměry Unie, mezi které patři především zabezpečení společné politiky týkající se azylu, doplňkové a dočasné ochrany. Unie je pak v souladu s článkem 78 SFEU za tímto účelem oprávněna prijímat opatření týkající se společného azylového systému obsahujícího mimo jiné i společný režim dočasné ochrany a postup při udělování a odnímání azylu. ${ }^{18}$

\footnotetext{
${ }^{16}$ ŠKAPOVÁ, L. Relokace jako nástroj řešení migrační krize EU. Praha, 2019. Diplomová práce. Univerzita Karlova, Fakulta právnická. Str. 8. Dostupné z: https://dspace.cuni. $\mathrm{cz} / \mathrm{bitstream} /$ handle/20.500.11956/108349/120334286. pdf?sequence=1\&isAllowed=y ${ }^{17}$ Lisabonská smlouva [online]. [cit. 2019-07-29], Dostupné z: https://eur-lex.europa. eu/legal-content/CS/TXT/HTML/?uri=LEGISSUM:ai0033\&from=EN

${ }^{18}$ ŠKAPOVÁ, L. Relokace jako nástroj řešení migrační krize EU. Praha, 2019. Diplomová práce. Univerzita Karlova, Fakulta právnická. Str. 9. Dostupné z: https://dspace.cuni. $\mathrm{cz} / \mathrm{bitstream} /$ handle/20.500.11956/108349/120334286. pdf?sequence=1\&isAllowed=y
} 
Rozhodnutí Rady EU - žaloba České republiky ve světle rozhodnutí o relokaci a žaloby s ním související / Michael Pauly

Pokud jde o procedurální požadavky, použije se v oblasti azylové problematiky vždy rádný legislativní postup, a to pouze s výjimkou vyplývající z článku 78 odst. 3 SFEU, který stanoví, že „ocitnou-li se jeden nebo více členských států ve stavu nouze $v$ důsledku náhlého prílivu státních príslušniků třetích zemí, může Rada na návrh Komise přijmout ve prospěch dotyčných členských států dočasná opatření. Rada rozhoduje po konzultaci s Evropským parlamentem“.1920

\section{3 Žaloba ČR pro porušení relokačních povinností}

Jak již bylo v úvodu tohoto příspěvku nastíněno, Rada EU dvěma rozhodnutími přijatými v září roku 2015, konkrétně rozhodnutím prijatým dne 14. září 2015 č. 2015/1523 a rozhodnutím přijatým dne 22. září č. 2015/1601, zavedla provizorní a naléhavý program na přemístění osob potřebujících mezinárodní ochranu. Na základě výše uvedených rozhodnutí se členské státy zavázaly k přemístění osob potřebujících mezinárodní ochranu z území Italské republiky a Řecké republiky. ${ }^{21}$

Rozhodnutí Rady stanoví povinnost členským státům nabídnout každé tři měsíce dostupná místa k přemístění osob

\footnotetext{
${ }^{19}$ Článek 78 odst. 3 SFEU.

${ }^{20}$ ŠKAPOVÁ, L. Relokace jako nástroj řešení migračni krize EU. Praha, 2019. Diplomová práce. Univerzita Karlova, Fakulta právnická. Str. 9. Dostupné z: https://dspace.cuni. $\mathrm{cz} / \mathrm{bitstream} / \mathrm{handle} / 20.500 .11956 / 108349 / 120334286$. pdf?sequence=1\&isAllowed=y ${ }^{21}$ Žalobní důvody a hlavní argumenty, žaloba podaná dne 22. prosince 2017 - Evropská komise v. Česká republika, sp. zn. C-718/17. Dostupné z: https://eur-lex.europa.eu/ legal-content/CS/TXT/PDF/?uri=CELEX:62017CN0719\&from=CS
} 
potřebujících mezinárodní ochranu, a to z důvodu zajištění rychlého a řádného postupu přemístění, přičemž Česká republika od srpna 2016 neprovedla žádné přemístění a ani nenabídla žádná nová místa. ${ }^{22}$

Evropská komise dne 15. června 2017 zaslala výzvu třem evropským státům, in concreto České republice, Mad'arské republice a Polské republice $v$ důsledku porušení těmito státy prijatých povinností. Touto výzvou tak Evropská komise zahájila řizení o neplnění povinností v souvislosti s programem přerozdělování migrantů dle rozhodnutími stanovených kvót. ${ }^{23}$

Česká republika dne 13. července 2017 reagovala na výzvu Evropské komise s tím, že výtky rezolutně odmítá, nebot’ podle jejího stanoviska nedochází k chybě na její straně, nýbrž na straně Italské republiky, jakož i Řecké republiky, a to $z$ důvodu nedostatečné součinnosti úřadů těchto zemí; tím dle názoru České republiky došlo $\mathrm{k}$ bránění v úspěšném přerozdělování. ${ }^{24}$

Odpověd' České republiky nebyla shledána dostatečnou, a proto se Evropská komise rozhodla v řizení přistoupit k dalšímu kroku, kterým bylo vydání odůvodněného stanoviska

\footnotetext{
${ }^{22}$ Relokace: Komise zahajuje řizení o nesplněni povinnosti proti České republice, Mad'arsku a Polsku [online]. [cit. 2019-08-08]. Dostupné z: https://europa.eu/rapid/ press-release_IP-17-1607_cs.htm

${ }^{23}$ Relokace: Komise zahajuje řizení o nesplněni povinnosti proti České republice, Mad'arsku a Polsku [online]. [cit. 2019-08-08]. Dostupné z: https://europa.eu/rapid/ press-release_IP-17-1607_cs.htm

${ }^{24}$ Komisi neuspokojila odpověd' České republiky na výtky ohledně neplněni kvót. Přistupuje do další fáze řízení [online]. [cit. 2019-08-08]. Dostupné z: https://telicka. eu/cs/articles/detail/756
} 
ze dne 26. července $2017^{25}$, které je považováno za formální žádost o zajištění souladu skutečného stavu s právem Evropské unie. České republice (stejně tak jako Mad'arské republice a Polské republice) byla též udělena jednoměsíční Ihůta $\mathrm{k}$ reakci na toto odůvodněné stanovisko. ${ }^{26}$ Česká republika na odůvodněné stanovisko reagovala. Reakce ovšem opětovně nebyla považována za uspokojivou a dostatečnou, v důsledku čehož se Evropská komise rozhodla věc předložit Soudnímu dvoru za účelem určení, zda Česká republika nesplnila povinnosti, které pro ni z rozhodnutí v oblasti přemistování vyplývají.

Co do petitu v žalobě C-719/17, která byla Soudnímu dvoru doručena dne 22. prosince 2017, Evropská komise navrhuje, aby Soudní dvůr:

„1. určil, že Česká republika tím, že neoznamuje v pravidelných intervalech a ani alespoň každé tři měsíce náležitý počet žadatelů, kteři by mohli být rychle přemístěni na její území, nesplnila povinnosti, které pro ni vyplývají z čl. 5 odst. 2 Rozhodnutí Rady (EU) 2015/1523 ze dne 14. zárí 2015, kterým se stanoví dočasná opatření $v$ oblasti mezinárodní ochrany ve prospěch Itálie a Řecka, a čl. 5 odst. 2 Rozhodnutí Rady (EU) 2015/1601 ze dne 22. zárí 2015, kterým se stanoví dočasná opatření $v$ oblasti mezinárodní

\footnotetext{
${ }^{25}$ Žalobní důvody a hlavní argumenty, žaloba podaná dne 22. prosince 2017 - Evropská komise v. Česká republika, sp. zn. C-718/17. Str. 2. Dostupné z: https://eur-lex.europa. eu/legal-content/CS/TXT/PDF/?uri=CELEX:62017CN0719\&from=CS

${ }^{26}$ Komisi neuspokojila odpověd' České republiky na výtky ohledně neplnění kvót. Přistupuje do další fáze řizení [online]. [cit. 2019-08-08]. Dostupné z: https://telicka. $\mathrm{eu} / \mathrm{cs} /$ articles/detail/756
} 
ochrany ve prospěch Itálie a Řecka, a tedy ani dalši povinnosti týkající se relokace stanovené $v$ čl. 5 odst. 4 až 11 obou výše uvedených rozhodnutí Rady; ${ }^{27}$

2. uložil České republice náhradu nákladů řízeni.."28

\section{Mad’arská republika, Polská republika a Slovenská republika}

Jak již bylo shora uvedeno, Česká republika nebyla jedinou zemí, která se dle názoru Evropské komise dopustila porušení relokačních povinností a komu v důsledku toho Evropská komise zaslala výzvu. Dalšími obeslanými státy byly Mad’arská republika a Polská republika.

Z takto obeslaných států Česká republika a zprvu ani Polská republika žádné dalši kroky nepodnikly. Naproti tomu Mad’arská republika a vedle ní též Slovenská republika, které podobně jako Česká republika hlasovaly v rámci Rady EU proti přijetí rozhodnutí ze dne 22. záři č. 2015/1601, o povinném přijímání migrantů a stanovení migračních kvót, se žalobou u Soudního dvora domáhají toho, aby Soudní dvůr rozhodnutí č. 2015/1601 zrušil. Přitom uplatňuji důvody, jimiž má být prokázáno, že přijetí tohoto rozhodnutí trpí procesními vadami či vadami spojenými s volbou nenáležitého právního základu a není způsobilé $k$ řešení migrační krize ani není $k$ tomu účelu

\footnotetext{
${ }^{27}$ Žalobní návrh, žaloba podaná dne 22. prosince 2017 - Evropská komise v. Česká republika, sp. zn. C-718/17. Dostupné z: https://eur-lex.europa.eu/legal-content/CS/ TXT/PDF/?uri=CELEX:62017CN0719\&from $=$ CS

${ }^{28}$ Žalobní návrh, žaloba podaná dne 22. prosince 2017 - Evropská komise v. Česká republika, sp. zn. C-718/17. Dostupné z: https://eur-lex.europa.eu/legal-content/CS/ TXT/PDF/?uri=CELEX:62017CN0719\&from $=$ CS
} 
nezbytné. ${ }^{29}$ Během řizení před Soudním dvorem vstoupila do řizení navíc též Polská republika, ovšem v postavení vedlejšího účastníka, z důvodu přímé podpory Slovenské republiky a Mad'arské republiky.

Soudní dvůr ovšem žalobu Slovenské republiky a Mad'arské republiky zamítl, a to $v$ plném rozsahu s tím, že nejprve odmítl argument, podle něhož článek 78 odst. 3 SFEU vyžaduje konzultaci s Evropským parlamentem, je-li opatření přijímáno na základě tohoto ustanovení, tzn., podle něhož měl být použit tzv. legislativní postup. V této souvislosti Soudní dvưr konstatoval, že legislativní postup se použije pouze tehdy, pokud na něj ustanovení smluv výslovně odkazuje. Jelikož v článku 78 odst. 3 SFEU není legislativní postup nikterak zmíněn, rozhodnutí č. 2015/1601 mohlo být dle názoru Soudního dvora přijato nelegislativním postupem, tj., že v případě napadeného rozhodnutí jde podle tohoto názoru o nelegislativní právní akt. Na základě tohoto závěru pak Soudní dvůr rovněž odmítl argumentaci směřující k základnímu aspektu respektování účasti vnitrostátních parlamentů na přijetí rozhodnutí č. 2015/1601 a konstatoval, že při přijímání daného rozhodnutí nemusel být požadavek účasti vnitrostátních parlamentů respektován, protože jde o nelegislativní právní akt a protože takový požadavek platí pouze pro přijímání aktů legislativních. ${ }^{30}$

\footnotetext{
${ }^{29}$ Soudní dvůr Evropské unie. TISKOVÁ ZPRÁVA ze dne 6. záři 2017, č. 91/17. Dostupné z: https://curia.europa.eu/jcms/upload/docs/application/pdf/2017-09/cp170091cs.pdf ${ }^{30}$ Soudní dvůr Evropské unie. TISKOVÁ ZPRÁVA ze dne 6. záři 2017, č. 91/17. Dostupné z: https://curia.europa.eu/jcms/upload/docs/application/pdf/2017-09/cp170091cs.pdf
} 


\section{Závěr}

Snaha o jakoukoliv predikci ve věci rozhodnutí Soudního dvora o žalobě České republiky, Mad'arské republiky a Polské republiky by se jevilo přinejmenším jako krátkozraké, nebot’ jde o historicky první připad žaloby tohoto typu a nelze tak přesvědčivě a s jistotou tvrdit, že došlo k porušení práva Evropské unie členskými státy.

V návaznosti na rozhodnutí Soudního dvora ve věci žaloby Mad'arské republiky, Slovenské republiky a Polské republiky v postavení vedlejšího účastníka, kterou se státy domáhaly zrušení rozhodnutí Rady EU č. 2015/1601 z důvodu nedokonalosti primárního práva spočívající v absenci požadavku na prijetí rozhodnutí v souladu s pravidly rádného legislativního procesu, nelze v důsledku negativního stanoviska Soudního dvora $\mathrm{k}$ této žalobě očekávat příznivý výsledek.

\section{POUŽITÉ PRAMENY}

Komisi neuspokojila odpověd' České republiky na výtky ohledně neplnění kvót. Přistupuje do dalši fáze řizení [online]. [cit. 2019-08-08]. Dostupné z: https://telicka.eu/ cs/articles/detail/756

KRÁL, R. Acta Universitatis Carolinae. Iuridica. 2010, 3, str. 21-31 [online]. [cit. 2019-07-26]. Dostupné z: https:// cupress.cuni.cz/ink2_stat/dload.jsp?prezMat=87969

Lisabonská smlouva - pozměňující Smlouvu o Evropské unii a Smlouvu o založení Evropského společenství, ze dne 13. prosince 2007. Úř. věst. C 306,17 . prosince 2007 , s. 1-271. 
Rozhodnutí Rady EU - žaloba České republiky ve světle rozhodnutí o relokaci a žaloby s ním související / Michael Pauly

Lisabonská smlouva [online]. [cit. 2019-07-29]. Dostupné z: https://eur-lex.europa.eu/legal-content/CS/TXT/HTML/ ?uri=LEGISSUM:ai0033\&from=EN

Questions and Answers on Relocation [online]. [cit. 2019-0802]. Dostupné z: https://www.easo.europa.eu/operational -support/hotspot-relocation/relocation/questions-and -answers-relocation

Relokace: Komise zahajuje rízení o nesplnění povinnosti proti České republice, Mad'arsku a Polsku [online]. [cit. 2019-08-08]. Dostupné z: https://europa.eu/rapid/press -release_IP-17-1607_cs.htm

SFEU, článek 78 odst. 3.

Slovníček pojmů - azyl [online]. [cit. 2019-07-29]. Dostupné z: https://www.mvcr.cz/migrace/clanek/slovnicek-pojmu. aspx

Slovníček pojmů - dublinský systém [online]. [cit. 2019-07-29]. Dostupné z: https://www.mvcr.cz/migrace/clanek/slovnicek -pojmu.aspx

Slovniček pojmů - imigrace [online]. [cit. 2019-07-29]. Dostupné z: https://www.mvcr.cz/migrace/clanek/slovnicek -pojmu.aspx

Slovniček pojmů - žadatel o azyl [online]. [cit. 2019-07-29]. Dostupné z: https://www.mvcr.cz/migrace/clanek/slovnicek -pojmu.aspx

Smlouva o fungování Evropské unie (konsolidované znění). Úř. věst. C 326 ze dne 26. řijna 2012, s. 47-390.

Soudní dvůr Evropské unie. TISKOVÁ ZPRÁVA ze dne 6. zárí 2017, č. 91/17. Dostupné z: https://curia.europa.eu/jcms/ upload/docs/application/pdf/2017-09/cp170091cs.pdf

Souhrnné informace o postupu MV v problematice relokací [online]. [cit. 2019-08-02]. Dostupné z: https://www.mvcr. 
Rozhodnutí Rady EU - žaloba České republiky ve světle rozhodnutí o relokaci a žaloby s ním související / Michael Pauly

$\mathrm{cz/migrace/clanek/souhrnne-informace-o-postupu-mv-v}$ -problematice-relokaci.aspx

ŠKAPOVÁ, L. Relokace jako nástroj řešení migrační krize EU. Praha, 2019. Diplomová práce. Univerzita Karlova, Fakulta právnická. Dostupné z: https://dspace.cuni.cz/ bitstream/handle/20.500.11956/108349/120334286.pdf? sequence=1\&isAllowed $=y$

Zákon č. 326/1999 Sb., zákon o pobytu cizinců na území České republiky a o změně některých zákonů, § 1 odst. 2. Zákon č. 325/1999 Sb., o azylu, § 2 odst. 2.

Žalobní důvody a hlavní argumenty, žaloba podaná dne 22. prosince 2017 - Evropská komise v. Česká republika, sp. zn. C-718/17. Dostupné z: https://eur-lex.europa.eu/legalcontent/CS/TXT/PDF/?uri=CELEX:62017CN0719\&from=CS 